\title{
Biomass and estimated production, and feeding pressure on zooplankton of chaetognaths in the Yellow Sea, China
}

\author{
Yuanzi Huo ${ }^{1,2, *}$, Qiao Liu ${ }^{3}$, Fang Zhang ${ }^{1}$, Chaolun $\mathrm{Li}^{1}$, Zhencheng $\mathrm{Tao}^{1}$, Hongsheng $\mathrm{Bi}^{2}$, Chunlei Fan ${ }^{4}$, \\ Jianheng Zhang ${ }^{3}$, and Song Sun ${ }^{1}$
${ }^{1}$ Key Laboratory of Marine Ecology and Environmental Sciences, Institute of Oceanology, Chinese Academy of Sciences, Qingdao, China
${ }^{2}$ Chesapeake Biological Laboratory, University of Maryland Center for Environmental Science, Maryland, United States ${ }^{3}$ College of Marine Ecology and Environment, Shanghai Ocean University, Shanghai, China
${ }^{4}$ Biology Department, Patuxent Environmental \& Aquatic Research Laboratory, Morgan State University, Maryland, United States

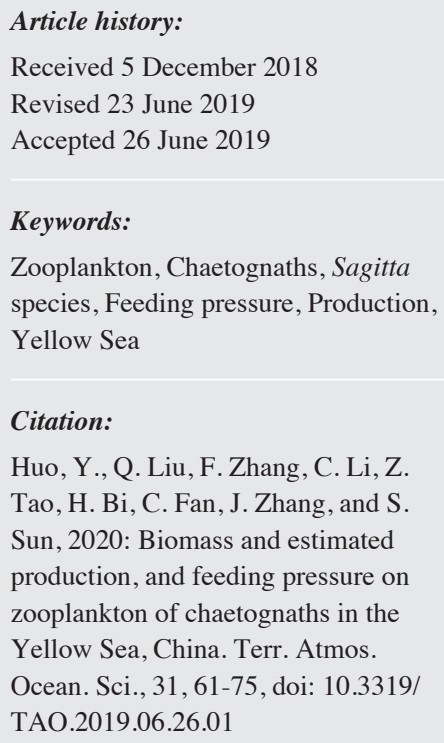

\begin{abstract}
The biomass and estimated production, feeding rate of chaetognaths were studied in the Yellow Sea. Sagitta crassa, Sagitta enflata, Sagitta bedoti, and Sagitta nagae were found during the study period, and S. crassa and S. nagae were the dominant species. The mean chaetognath biomass was in the range of $2.56-5.57 \mathrm{mg}$ DM $\mathrm{m}^{-3}$, and $S$. crassa and $S$. nagae comprised $49-90$ and $10-33 \%$, respectively. The geographical distribution pattern was differed between different species. The annual average estimated feeding rate and production of chaetognaths was evaluated as $55.24 \mathrm{mg} \mathrm{C} \mathrm{m}^{-3}$ year-1 and $15.90 \mathrm{mg} \mathrm{C} \mathrm{m}^{-3}$ year $^{-1}$, respectively. The body length of Sagitta species less than $9-11 \mathrm{~mm}$ had relatively high feeding rate in August, September, and December because of their relatively high total biomass, while the body length with $8-16,11-15$, and $6-16 \mathrm{~mm}$ groups had relatively high feeding rate in March, May, and June, respectively. The average feeding pressure on zooplankton biomass and production by chaetognaths could be evaluated as 1.07 and $18.95 \%$, respectively, and the biomass and production of small copepods, and nauplius and copepodite of large copepods would be seriously impacted during whole year.
\end{abstract}

\section{INTRODUCTION}

The chaetognaths are major pelagic invertebrates which are extremely abundant in marine systems, often second only to copepods in number (Feigenbaum and Maris 1984). Chaetognaths are well known as important carnivores of secondary producers in marine ecosystems (Terazaki 2001), and their predation may have a significantly impact on copepod population dynamics (Reeve 1970; Sameoto 1972), especially under conditions of low environmental productivity (Kimmerer 1984; Øresland 1990).

Biomass, production and consumption of chaetognaths and dominant chaetognath species have been reported in some sea areas. Chaetognaths had a mean biomass of 0.109

\footnotetext{
* Corresponding author

E-mail:yuanzi1979-11@163.com
}

- $0.146 \mathrm{mg} \mathrm{C} \mathrm{m} \mathrm{m}^{-3}$ in Southern Ocean (Kruse et al. 2010). The yearly production and required a prey production of $S$. crass $a$ was estimated to be $3.8 \mathrm{~g} \mathrm{C} \mathrm{m}^{-2}$ and $13.1 \mathrm{~g} \mathrm{C} \mathrm{m}^{-2}$ year $^{-1}$ in Tokyo Bay, respectively. Chaetognaths were identified as the second most important group composing at times up to $30 \%$ (mean $14.7 \%$ ) of total zooplankton abundance in the pelagic system of the Prince Edward Islands (Froneman and Pakhomov 1998). Trophic ecology of chaetognaths or dominant chaetognath species was studied by many researchers, which could be indicated by the feeding pressure on zooplankton biomass and production. Feeding pressure of chaetognaths on zooplankton varied significantly under different environmental conditions and between different sea areas. Kehayias et al. (2005) reported that the feeding pressure of chaetognaths on zooplankton standing stocks was $0.02-2.76 \%$ in Aegean Sea, while Baier and Purcell (1997b) 
reported that chaetognaths could consume up to $44 \% \mathrm{~d}^{-1}$ of standing stocks of large copepods in South Atlantic Bight. Feeding pressure of Sagitta elegans on zooplankton production was only $0.7-1.0 \%$ in St. Margaret's Bay (Sameoto 1972), while the dominant species Sagitta tenuis consumed up to 5 - $15 \%$ of zooplankton production in Chesapeake Bay (Canino and Grant 1985).

The Yellow Sea is a marginal sea of the northwest Pacific, surrounded by the eastern coast of China and the Korean peninsula, with a mean depth of $44 \mathrm{~m}$ and maximum depth of $103 \mathrm{~m}$, and as a shallow shelf water, the Yellow Sea contains complex physical environments and is affected greatly by climatic conditions (Huo et al. 2012). The Yellow Sea is a major fishing ground, and the bordering countries derive a substantial part of their food from fishing in coastal waters. It is our responsibility to preserve the health of this productive ecosystem in order to sustain fishing in the future. The relationships between zooplankton and higher trophic levels in the Yellow Sea was a key scientific question, and how to describe variations of zooplankton biomass and production and make it easier to be modeled in the Yellow Sea ecosystem is the main purpose (Sun et al. 2010). The zooplankton functional groups approach, which is considered a good method of linking the structure of food webs and the energy flow in the ecosystems, is used to describe this process in the Yellow Sea ecosystem (Sun et al. 2010).

Chaetognaths is one gelatinous carnivorous zooplankton groups in the Yellow Sea (Sun et al. 2010), which seem to be opportunistically positioned to utilize secondary production that is ordinarily consumed by fish (Mills 1995). In addition, the chaetognaths group is also a food resource for fish (Sun et al. 2010). However, to our knowledge, there has few studies on chaetognaths in the Yellow Sea. Zuo et al. (2004) and Lee et al. (2016) described the relationship between distribution patterns of chaetognaths and environmental factors; Huo et al. (2010) reported that the life cycle of $S$. crassa in the Southern Yellow Sea; Kang et al. (2012) summarized that chaetognaths also showed a downward trend after the mid1990s, but high positive anomalies were observed in 2002 and 2006 in the Eastern Yellow Sea; Choi and Park (2013) found that the abundance of chaetognaths fluctuated around the long-term mean value during the past four decades in the western waters of the Korean Peninsula in the Yellow Sea.

However, the trophic ecology of chaetognaths is unknown in the Yellow Sea. Our hypothesis is that chaetognaths would require a significant prey production in the Yellow Sea. In this present study, the biomass, and estimated production and feeding of chaetognaths as well as the feeding pressure of chaetognaths on zooplankton biomass and secondary production were evaluated based on data obtained from the six cruises during period from September 2006 to August 2007 in the Yellow Sea, which is very important for "parameterization" of food web structure models of the Yellow Sea.

\section{MATERIAL AND METHODS}

\subsection{Study Area and Sampling Methods}

The chaetognaths was sampled during six cruises on the $\mathrm{R} / \mathrm{V}$ "Beidou" in the Yellow Sea during period from September 2006 to August 2007. Figure 1 shows the location of transects and sampling stations during these six cruises. The maximum water depth of these stations was less than $100 \mathrm{~m}$. Vertical profiles of temperature and salinity were recorded at each station with a Sea-Bird (SBE 25) CTD instrument lowered and retrieved from the sea surface to near the sea bed. Seawater samples for the measurement of chlorophyll $a(\mathrm{Chl} a$ ) were collected at different depths from the sea surface to near the sea bed, filtered onto GF/F glass-fiber filters, extracted using $90 \%$ aqueous acetone and the concentration of $\mathrm{Chl} a$ determined fluorometrically using a Turner Designs fluorometer. Bad weather prevented experiments being done at some stations in certain cruises.

The chaetognaths were sampled using the conical plankton net with $500 \mu \mathrm{m}$ mesh size and $0.8 \mathrm{~m}$ mouth diameter (Wang and Wang 2003; Sun et al. 2010), which were towed vertically at $\sim 1 \mathrm{~m} \mathrm{~s}^{-1}$ from near the sea bottom of the water column to the sea surface. A TSK flow-meter and depth sensors were mounted at the mouth of the each net to measure the volume of water filtered and the sampling depth, respectively. After the nets were retrieved, the zooplankton samples were immediately preserved in 5\% neutralized formalin seawater solution. In the laboratory, the abundance of chaetognaths was all counted, and were enumerated under a dissecting microscope.

\subsection{Biomass Determination}

Only four chaetognath species, Sagitta crassa, Sagitta enflata, Sagitta bedoti, and Sagitta nagae, was found during the study period in the Yellow Sea. The biomass of each chaetognath species was determined based on the relationship between the dry weight and the body length. The biomass of $S$. crassa and $S$. enflata could be obtained based on the following equations: $W=0.197 L^{3.01}$ for $S$. crassa (Nagasawa 1984) and $W=0.0001352 L^{3.1545}$ for $S$. enflata (Feigenbaum 1979), respectively. Because the abundance of $S$. bedoti was rather low compared with other Sagitta species, and the body length of $S$. bedoti was similar to that of $S$. crassa, so the biomass of $S$. bedoti was evaluated according to the relationship between the dry weight and the body length of $S$. crassa. Total lengths of 170 undamaged live $S$. nagae were measured to the nearest $0.1 \mathrm{~mm}$. These samples were rinsed with distilled water to remove external salts, dried at $60^{\circ} \mathrm{C}$ for $24-36 \mathrm{~h}$, weighed to the nearest 0.1 $\mu \mathrm{g}$. The range of lengths was $8.50-25.75 \mathrm{~mm}$. The relationship between the dry weight and the body length of $S$. nagae could be described as following equation: $W=a L^{b}$ (Uye 1982), where $a$ and $b$ were the constant parameters. 


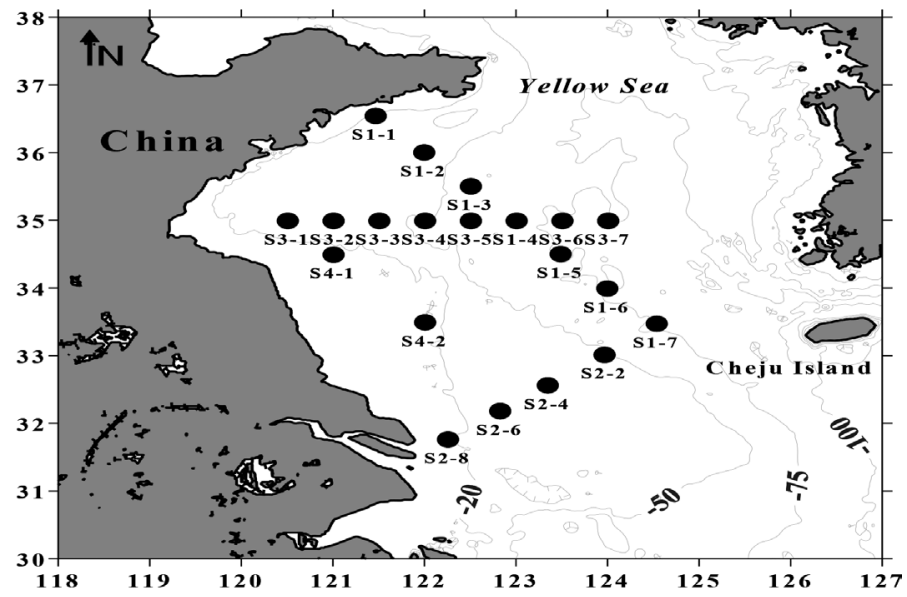

Fig. 1. Map of the study area and localities of the transects and sampling stations with isobaths of 20, 50, 75, and $100 \mathrm{~m}$.

\subsection{Production and Feeding Rate Evaluation}

According to Huo et al. (2012), the respiration rate of each Sagitta species for the feeding and production estimates was calculated based on the Ikeda and Motoda's physiological model (Ikeda and Motoda 1975, 1978). Respiration was expressed as carbon units $\left(R_{C}, \mathrm{mg} \mathrm{C}\right.$ animal $\left.{ }^{-1} \mathrm{~h}^{-1}\right)$ as the following equation, assuming an ammonia RQ of 0.97 (Gnaiger 1983): $R_{C}=R_{O 2} \times 0.97 \times 12 / 1000 \times 22.4$, where 12 is the molar mass of carbon $\left(\mathrm{g} \mathrm{mol}^{-1}\right), 22.4$ is the molar volume of oxygen $\left(\mathrm{L} \mathrm{mol}^{-1}\right)$ and $R_{O 2}$ is respiration rate $\left(\mu l \mathrm{O}_{2}\right.$ animal $^{-1} \mathrm{~h}^{-1}$ ) which was calculated as a function of body weight $(W)$ and temperature $\left(T,{ }^{\circ} \mathrm{C}\right): \ln R_{O 2}=-0.2512+$ $0.7886 \ln W+0.0490 T$, where $R_{O 2}$ is respiration rate $\left(\mu l \mathrm{O}_{2}\right.$ animal ${ }^{-1} \mathrm{~h}^{-1}$ ) and $W$ is body dry weight (mg animal ${ }^{-1}$ ) (Ikeda 1985). Equations of feeding and production of each Sagitta species were suggested as follows (Nagasawa 1991): $F=$ $1.6 R_{C}, P=0.46 R_{C}$, where $F$ is feeding and $P$ is production. The feeding and production per day of each Sagitta species were obtained as $F$ and $P$ multiplying the abundance of each Sagitta species (ind. $\mathrm{m}^{-3}$ ) and $24 \mathrm{~h}$.

In the Yellow Sea, the strong stratification appeared in the summer time from June to September resulted by the Yellow Sea Cold Bottom Water (YSCBW). During the summer time at the YSCBW sea area, S. enflata, S. nagae and $S$. bedoti were mostly distributed in the upper layer and outside the cold water mass sea area, but $S$. crassa inhabited mostly inside the thermocline (Zuo et al. 2004). So in the June, August, and September, when calculating the respiration rate of $S$. crassa at the YSCBW sea area, the parameter $T$ was the average temperature of the thermocline, while calculating the respiration rate of the other three Sagitta species, the parameter $T$ was the average temperature of water column upper the thermocline. And in other months when the strong stratification disappeared, the parameter $T$ was the average temperature of water column from sea surface to the bottom. Based on the results reported by Huo et al. (2012), we could confirm that S1-3, S1-4, S1-5, S1-6, S1-7, S3-2, S3-3, S3-4, S3-5, S3-6, S3-7 located inside the YSCBW sea area in June 2007, and S1-2, S1-3, S1-4, S1-5, S1-6, S1-7, S3-3, S3-4, S3-5, S3-6, S3-7 in August 2007, and S1-2, S1-3, S1-4, S1-5, S1-6, S1-7, S3-7 in September 2006, respectively.

\subsection{Feeding Pressure on the Zooplankton Biomass and Production}

Huo et al. (2012) reported the biomass $\left(\mathrm{mg} \mathrm{C} \mathrm{m}^{-3}\right)$ and estimated production $\left(\mathrm{mg} \mathrm{C} \mathrm{m}^{-3} \mathrm{~d}^{-1}\right)$ of zooplankton at the same sapling sites in the Yellow Sea. So the feeding pressure could be evaluated based on the feeding rate of each Sagitta species and total four Sagitta species divided by the biomass and production of zooplankton as follows: $F_{\text {Biomass }}=$ $F / B_{\text {Zooplankton }}, F_{\text {Production }}=F / P_{\text {Zooplankton }}$, where $F$ is feeding rate of chaetognaths, $F_{\text {Biomass }}$ is feeding pressure of chaetognaths on zooplankton biomass, $F_{\text {Production }}$ is feeding pressure of chaetognaths on zooplankton production, $B_{\text {Zooplankton }}$ is zooplankton biomass and $P_{\text {Zooplankton }}$ is zooplankton production, respectively.

\subsection{Data Analysis}

The sampling map and geographical distribution of chaetognath biomass were constructed using Surfer 8.0 software. Biomass, feeding rate and estimated production of chaetognaths were reported as mean values \pm standard deviation (mean $\pm \mathrm{SD}$ ). Rang and average of biomass $\left(\mathrm{mg} \mathrm{DM} \mathrm{m} \mathrm{m}^{-3}\right)$, feeding rate $\left(\mu \mathrm{g} \mathrm{C} \mathrm{m}^{-3} \mathrm{~d}^{-1}\right)$ and production $\left(\mu \mathrm{C} \mathrm{m}^{-3} \mathrm{~d}^{-1}\right.$ ) of four Sagitta species and total chaetognaths were calculated as the range between the lowest and highest value, and mean value from all sampling sites, respectively. Statistical analyses were conducted using SPSS 19.0.

Multivariate ordination techniques were used to analyze the relationship of environmental variables with the 
chaetognaths by CANOCO for Windows 4.5. The environmental parameters were adopted as the explanatory variables. All of these environmental parameters were $\log 10$ transformed before analysis. The chaetognath species data were $\log 10(x+1)$ transformed before analysis to obtain consecutive distributions. Detrended correspondence analysis (DCA) for the chaetognath species data was employed to decide whether linear or unimodal ordination methods should be applied in this study. DCA revealed that the maximum gradient length of the four axes was lower than 3 , therefore, redundancy analysis (RDA) was used. Monte Carlo simulation was used to test the significance of the environmental parameters to explain the chaetognaths data in the RDA.

\section{RESULTS}

\subsection{Biomass Distribution of Four Sagitta Species}

The total length-dry weight relationship of $S$. nagae is described by the following equation: $W=0.0565 L^{3.3426}$, where $W$ is dry weight $(\mu \mathrm{g})$ and $L$ is total length $(\mathrm{mm})$. The mean total biomass of chaetognaths in the Yellow Sea peaked in May 2007 with $5.57 \mathrm{mg} \mathrm{DM} \mathrm{m}^{-3}$, and was lowest in August 2007 with $2.56 \mathrm{mg} \mathrm{DM} \mathrm{m}^{-3}$, and in other months, the biomass was in the range of $2.85-4.12 \mathrm{mg} \mathrm{DM} \mathrm{m}^{-3}$ (Table 1). S. crassa and S. nagae comprised $49-90$ and $10-33 \%$ of the total biomass throughout the year, respectively. High biomass of $S$. crassa was mainly distributed at the northern part of the investigated area throughout the year (Fig. 2). S. enflata, the oceanic species, was mainly distributed at the southern part of the study area. In March 2007, relative high biomass of $S$. nagae located at the northern part of study area, while in other investigated months, it was mainly distributed at the central and southern part of the study area. $S$. bedoti had lowest biomass compared with other three Sagitta species during the study period in the Yellow Sea.

During the study period, the spatio-temporal distribution of the environmental variables varied between the investigated months. The results observed for these environmental variables were reported by Huo et al. (2012). The relationship between environmental factors and chaetognaths biomass in each month investigated was analyzed by RDA (Table 2 and Fig. 3). There were different significant environmental factors that explained the variability of the chaetognaths in the investigation months according to the RDA with forward selection. Surface salinity was found to statistically explain the variation in the composition of chaetognaths in September 2006. Bottom temperature was the significant environmental factor in December 2006, March 2007, May 2007, and August 2007, and Chl $a$, bottom salinity and surface salinity was also the significant environmental factor in December 2006, May 2007, and August 2007, respectively. During the study period in June 2007 , no environmental factor was significantly correlated with chaetognaths in the Yellow Sea.

\subsection{Estimated Feeding Rate and Production of Four Sagitta Species}

The mean total feeding rate and production of four $\mathrm{Sa}$ gitta species was also highest in May 2007 with 222.84 and $64.39 \mu \mathrm{g} \mathrm{C} \mathrm{m}^{-3} \mathrm{~d}^{-1}$, respectively, but was lowest in December 2006 with 115.74 and $33.28 \mu \mathrm{g} \mathrm{C} \mathrm{m}^{-3} \mathrm{~d}^{-1}$, respectively (Tables 1 and 3). In September 2006 and June, August 2007, chaetognaths also had high feeding rate and production (Huo et al. 2012), even though their body weights were relatively low in August and September (Tables 1 and 3). S. crassa and $S$. nagae had high feeding rate and production during the whole study period because of relatively their high biomass

Table 1. Rang and average of biomass $\left(\mathrm{mg} \mathrm{DM} \mathrm{m}^{-3}\right)$ of four Sagitta species and total chaetognaths in different investigated months in the Yellow Sea.

\begin{tabular}{c|c|ccccc}
\hline \multicolumn{2}{c|}{ Species } & Sagitta crassa & Sagitta enflata & Sagitta bedoti & Sagitta nagae & Total \\
\hline \multirow{2}{*}{ September 2006 } & Range & $0.01-5.49$ & $0-4.89$ & $0-0.86$ & $0-2.80$ & $0.44-6.27$ \\
& Average & $1.41 \pm 0.34$ & $0.77 \pm 0.31$ & $0.14 \pm 0.06$ & $0.53 \pm 0.18$ & $2.85 \pm 0.43$ \\
\hline \multirow{2}{*}{ December 2006 } & Range & $0.02-14.49$ & $0-0.38$ & $0-0.32$ & $0-3.80$ & $0.11-18.89$ \\
& Average & $2.24 \pm 0.84$ & $0.05 \pm 0.02$ & $0.06 \pm 0.02$ & $0.63 \pm 0.22$ & $2.97 \pm 1.08$ \\
\hline \multirow{2}{*}{ March 2007 } & Range & $0.01-27.48$ & $0-0.01$ & $0-0.07$ & $0-1.54$ & $0.08-29.03$ \\
& Average & $3.73 \pm 1.57$ & $0.0007 \pm 0.0007$ & $0.01 \pm 0.0042$ & $0.38 \pm 0.09$ & $4.12 \pm 1.64$ \\
\hline \multirow{2}{*}{ May 2007 } & Range & $0.07-33.16$ & $0-0.15$ & $0-6.10$ & $0-3.71$ & $0.52-33.48$ \\
& Average & $4.15 \pm 1.70$ & $0.01 \pm 0.01$ & $0.47 \pm 0.33$ & $0.93 \pm 0.23$ & $5.57 \pm 1.65$ \\
\hline \multirow{2}{*}{ June 2007 } & Range & $0-8.41$ & $0-0.23$ & $0-1.44$ & $0-5.14$ & $0.22-8.67$ \\
& Average & $2.38 \pm 0.65$ & $0.02 \pm 0.02$ & $0.12 \pm 0.08$ & $1.22 \pm 0.34$ & $3.74 \pm 0.69$ \\
\hline \multirow{2}{*}{ August 2007 } & Range & $0.05-7.25$ & $0-0.03$ & $0-0.13$ & $0-4.08$ & $0.14-11.32$ \\
& Average & $1.81 \pm 0.63$ & $0.0018 \pm 0.0018$ & $0.02 \pm 0.01$ & $0.74 \pm 0.27$ & $2.56 \pm 0.81$ \\
\hline
\end{tabular}


(a)

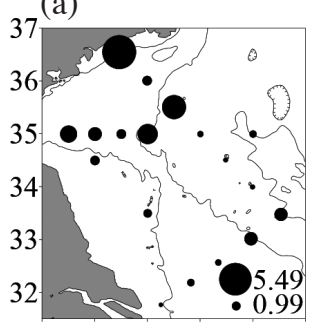

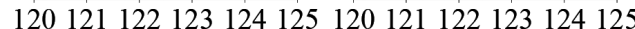

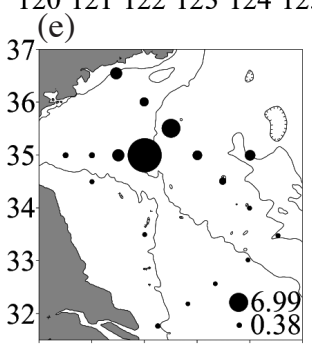

(b)

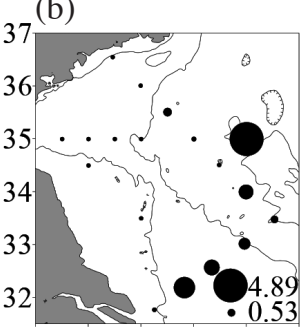

(c)

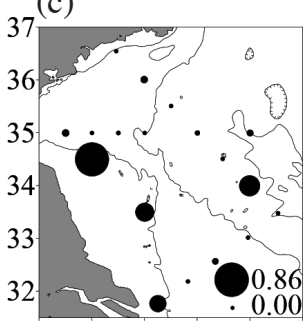

(d)
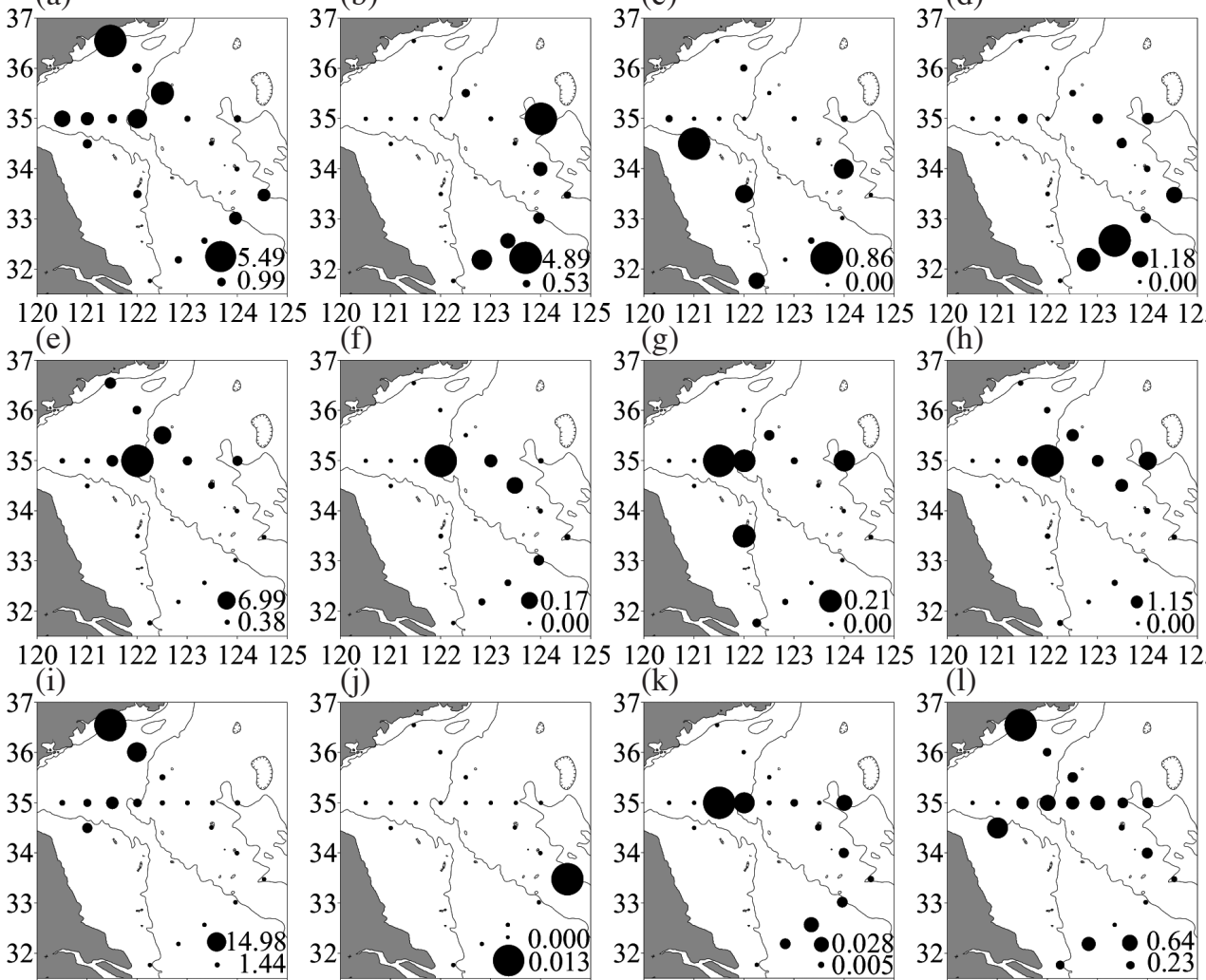

120121122123124125

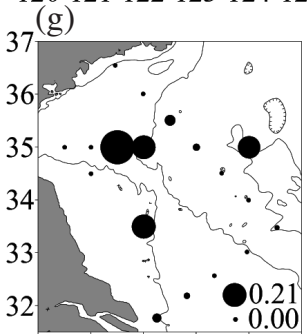

120121122123124125

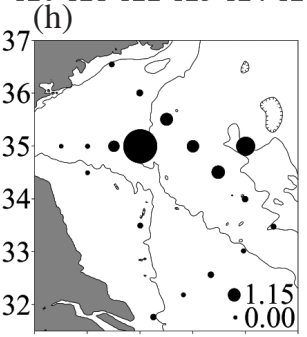

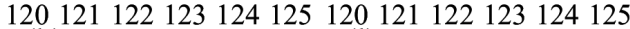
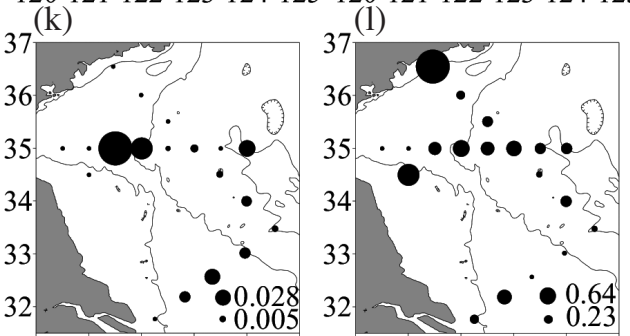

120121122123124125120121122123124125120121122123124125120121122123124125
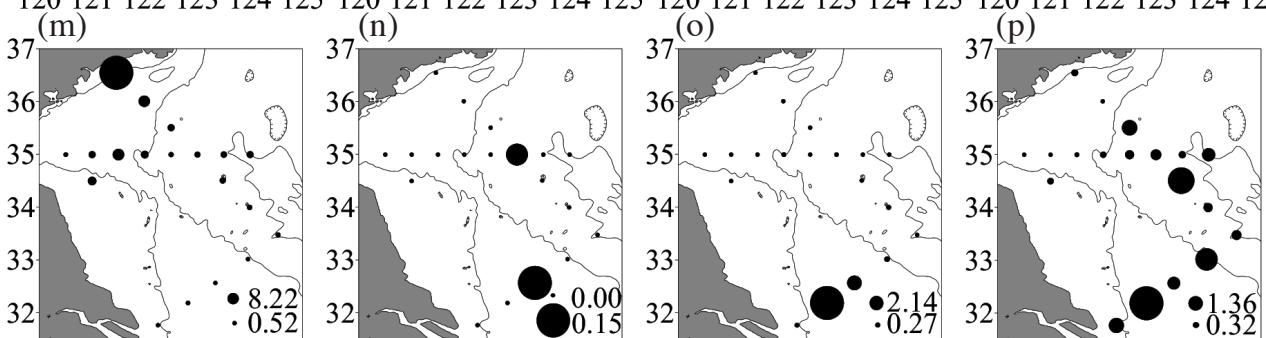

120121122123124125120121122123124125
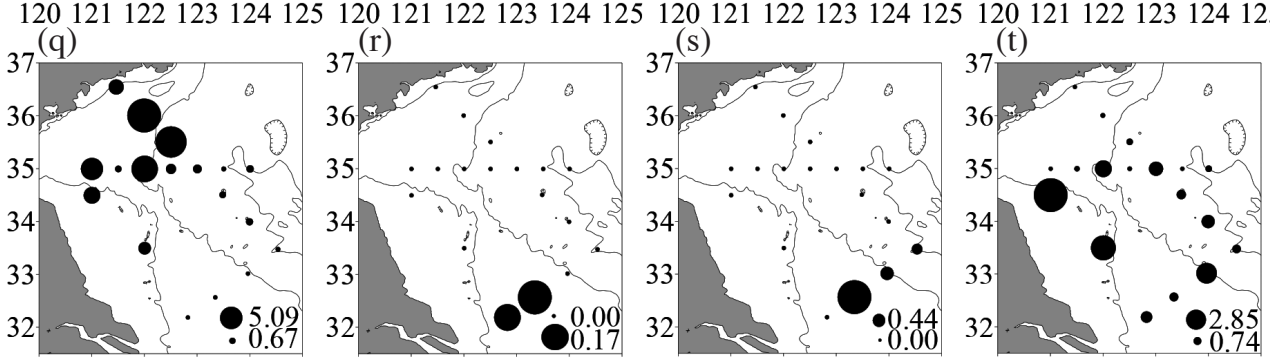

$\begin{array}{llllllllllll}120 & 121 & 122 & 123 & 124 & 125 & 120 & 121 & 122 & 123 & 124 & 125\end{array}$
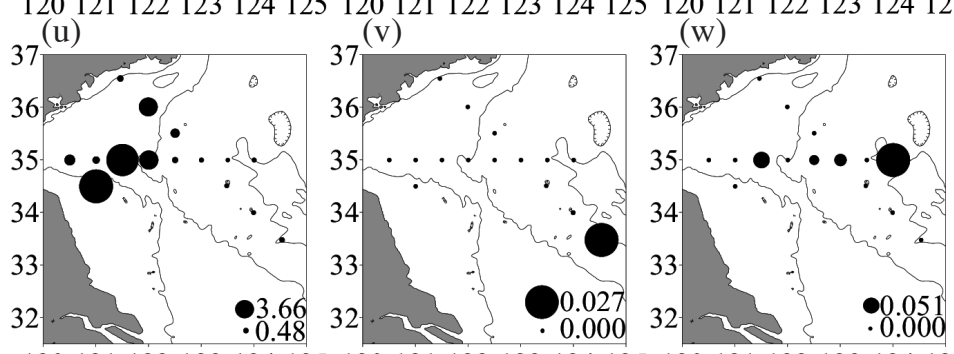

120121122123124125

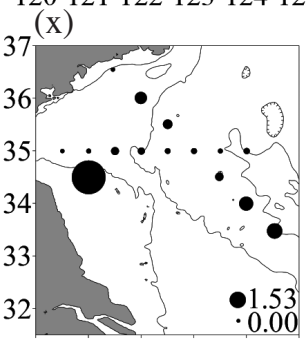

120121122123124125120121122123124125120121122123124125120121122123124125

Fig. 2. Biomass (mg DM m${ }^{-3}$ ) distribution of Sagitta crassa in September 2006 (a), December 2006 (e), March 2007 (i), May 2007 (m), June 2007 (q), and August 2007 (u); Sagitta enflata in September 2006 (b), December 2006 (f), March 2007 (j), May 2007 (n), June 2007 (r), and August 2007 (v); Sagitta bedoti in September 2006 (c), December 2006 (g), March 2007 (k), May 2007 (o), June 2007 (s), and August 2007 (w); Sagitta nagae in September 2006 (d), December 2006 (h), March 2007 (l), May 2007 (p), June 2007 (t), and August 2007 (x). 
Table 2. Variation partitioning analysis of the significant environmental factors on the chaetognaths assemblages in different investigated months in the Yellow Sea.

\begin{tabular}{c|ccccc}
\hline Month & Environmental factor & Eigenvalues & Variation explains solely/\% & $\boldsymbol{F}$ & $\boldsymbol{p}$ \\
\hline September 2006 & Surface salinity & 0.269 & 26.9 & 5.894 & 0.002 \\
\hline \multirow{2}{*}{ December 2006 } & Bottom temperature & 0.209 & 20.9 & 4.227 & 0.046 \\
& Chl $a$ & 0.186 & 18.6 & 4.597 & 0.040 \\
\hline \multirow{2}{*}{ March 2007 } & Bottom temperature & 0.700 & 70.0 & 39.698 & 0.002 \\
\hline \multirow{2}{*}{ May 2007 } & Bottom temperature & 0.239 & 23.9 & 5.332 & 0.008 \\
& Bottom salinity & 0.277 & 27.7 & 9.147 & 0.004 \\
\hline \multirow{2}{*}{ August 2007 } & Surface salinity & 0.424 & 42.4 & 9.569 & 0.004 \\
& Bottom temperature & 0.175 & 17.5 & 5.229 & 0.010 \\
\hline
\end{tabular}
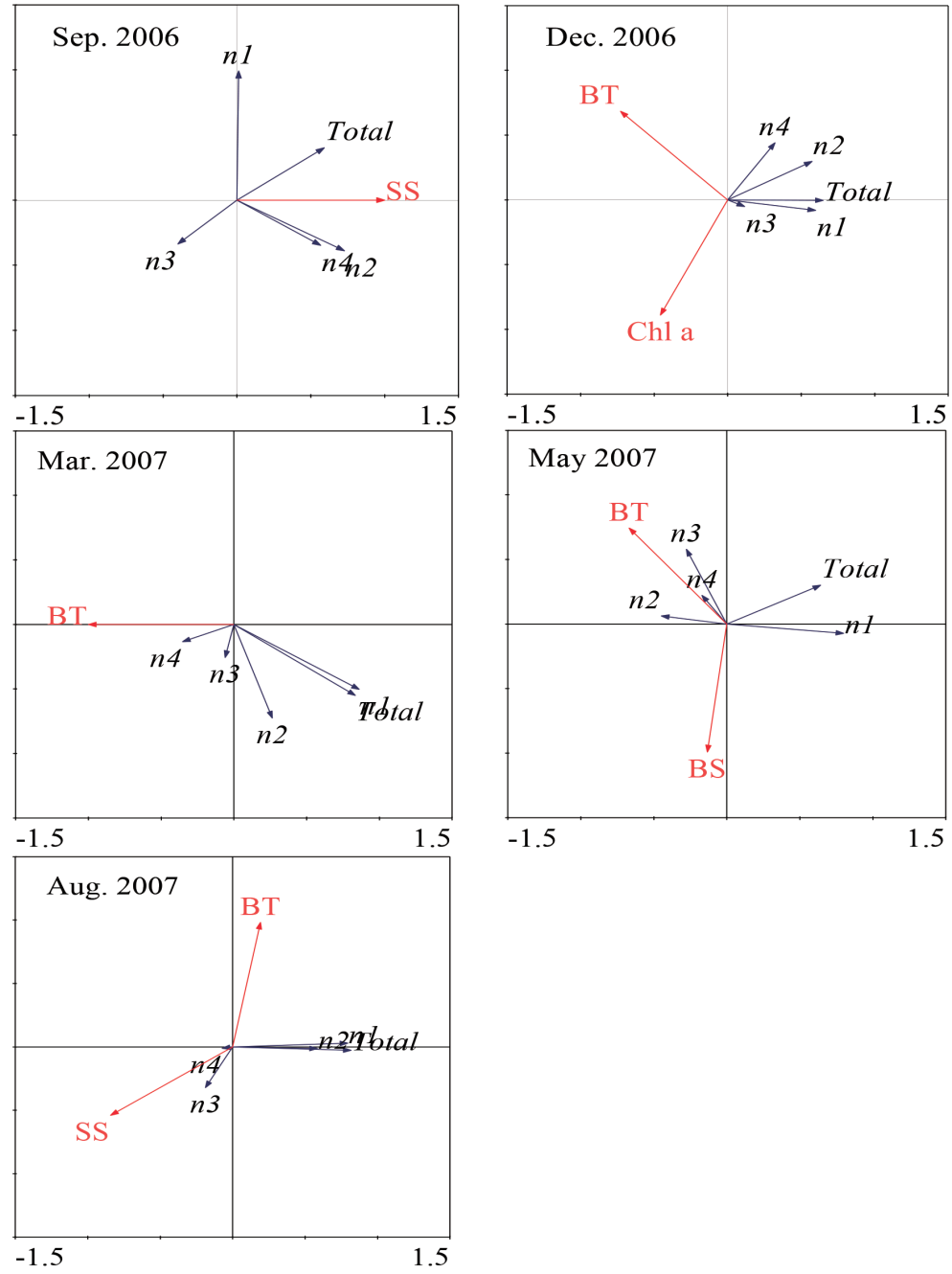

Fig. 3. Correlation plots of the redundancy analysis (RDA) for the relationship between the environmental variables and chaetognath species. The numbers with letters represent the following species: $n 1$ represents Sagitta crassa, $n 2$ Sagitta nagae, $n 3$ Sagitta bedoti, $n 4$ Sagitta enflata, $n 5$ represents total chaetognath biomass. 


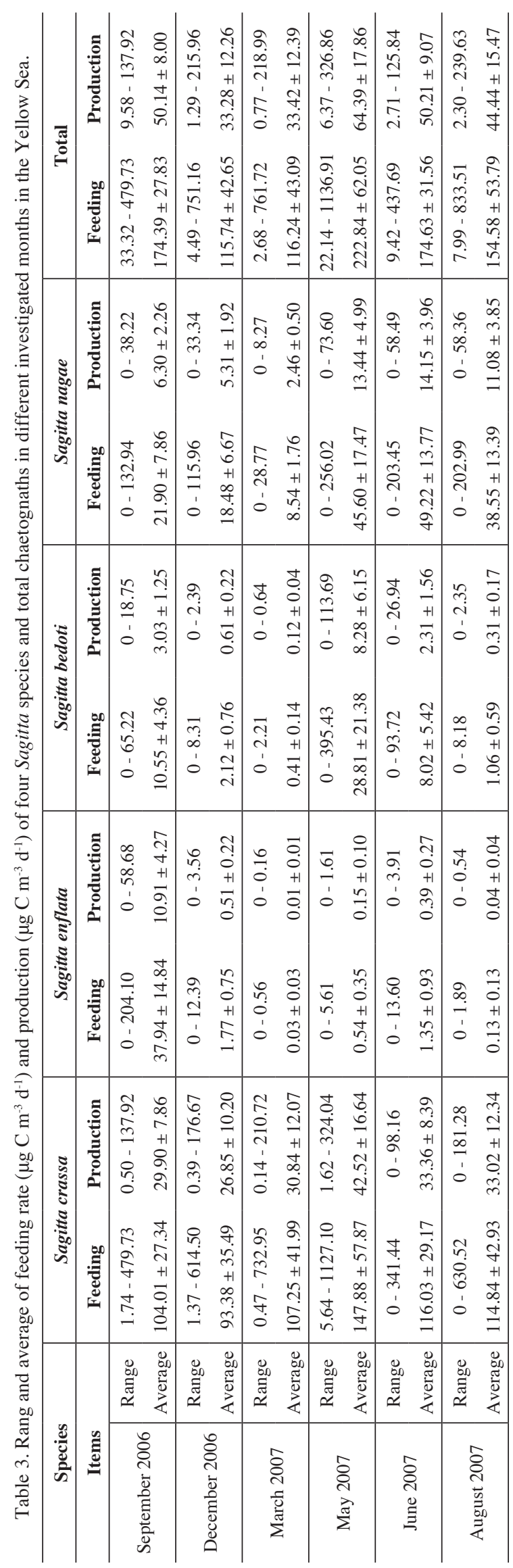

compared with other two species. The annual average feeding rate and production of chaetognaths in the study area was evaluated as 55.24 and $15.90 \mathrm{mg} \mathrm{C} \mathrm{m}^{-3}$ year $^{-1}$, respectively. Chaetognaths had relatively high feeding rate and production at sampling stations of northern part and along the transect near Yangtze estuary in September 2006; in the central part of Yellow Sea in December 2006; at the coast of Shandong peninsula in March and May 2007; and along the coast of Yellow Sea in June and August 2007 (Fig. 4).

\subsection{Feeding Rate of Different Body Length of Chaetognaths}

Feeding rate of different body length of chaetognaths was analyzed at the interval of $1 \mathrm{~mm}$ which was showed in Fig. 5. The feeding rate of $5-9 \mathrm{~mm}$ body length of chaetognaths was relatively higher than those of other chaetognath body length groups in September 2006 and August 2007. In December 2006, the 7 - 11 mm body length of chaetognaths had relatively high feeding rate than other chaetognath body length groups. And in the March, May, and June of 2007, the relatively high feeding rate of chaetognaths was in the body length of $8-16,11-15$, and $6-16 \mathrm{~mm}$ groups, respectively.

\subsection{Feeding Pressure on Zooplankton Biomass and Production}

Based on the results of zooplankton biomass and production obtained from the same sampling sites of the Yellow Sea reported by Huo et al. (2012), the feeding pressure on zooplankton biomass and production by four Sagitta species in the Yellow Sea could be evaluated as Table 4 showed. Feeding pressure on zooplankton biomass and production was lowest in May 2007 with 0.80 and 13.54\%, respectively. Feeding pressure on zooplankton production was as high as $26.90 \%$, but was only $0.99 \%$ on zooplankton biomass in March 2007. In other investigated months, the feeding pressure was in the range of $1.05-1.22$ and $14.50-21.21 \%$ on zooplankton biomass and production, respectively. Based on these data, the annual average feeding pressure on zooplankton biomass and production was evaluated as 1.07 and $18.95 \%$, respectively, in the Yellow Sea. $S$. crassa and $S$. nagae contributed most to the feeding pressure on zooplankton biomass and production during the whole study period because of their relatively high biomass compared with other two species (Table 4).

\section{DISCUSSION}

\subsection{Methods of Evaluating the Feeding Rate of Chaetognaths}

Feeding rate of chaetognaths can be evaluated as the following equation proposed by Bajkov (1935): $F R i=N P C$ $\times 24 / D T(h)$, where $F R i$ is daily feeding rate (mean number 

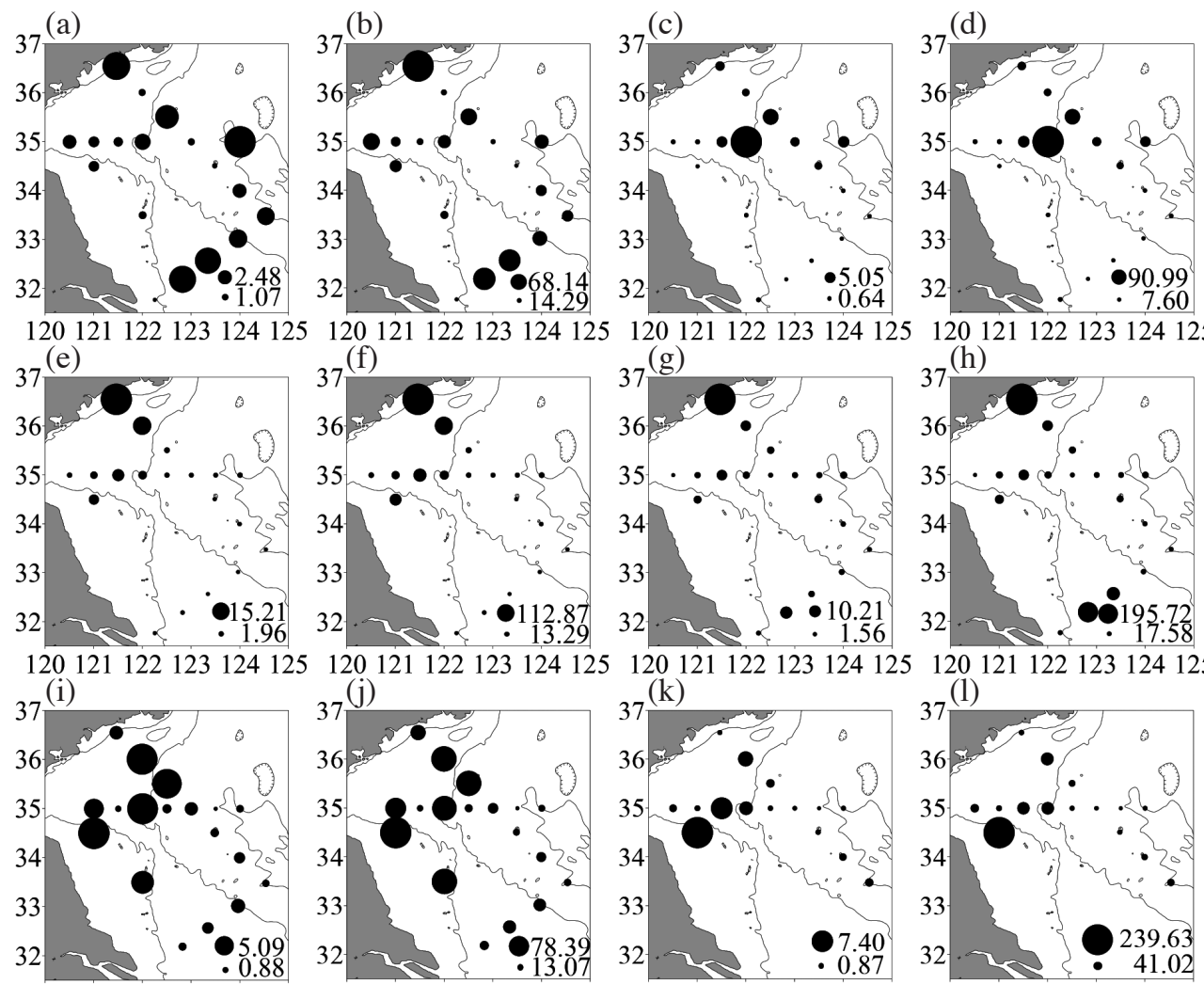

$120121122123124125 \quad 120121122123124125 \quad 120121122123124125120121122123124125$

Fig. 4. Geographical distribution of biomass $\left(\mathrm{mg} \mathrm{DM} \mathrm{m} \mathrm{m}^{-3} \mathrm{~d}^{-1}\right)$ and production $\left(\mu \mathrm{g} \mathrm{C} \mathrm{m}^{-3} \mathrm{~d}^{-1}\right)$ for the total four Sagitta species in September 2006 (a) and (b), December 2006 (c) and (d), March 2007 (e) and (f), May 2007 (g) and (h), June 2007 (i) and (j), August 2007 (k) and (l), respectively.

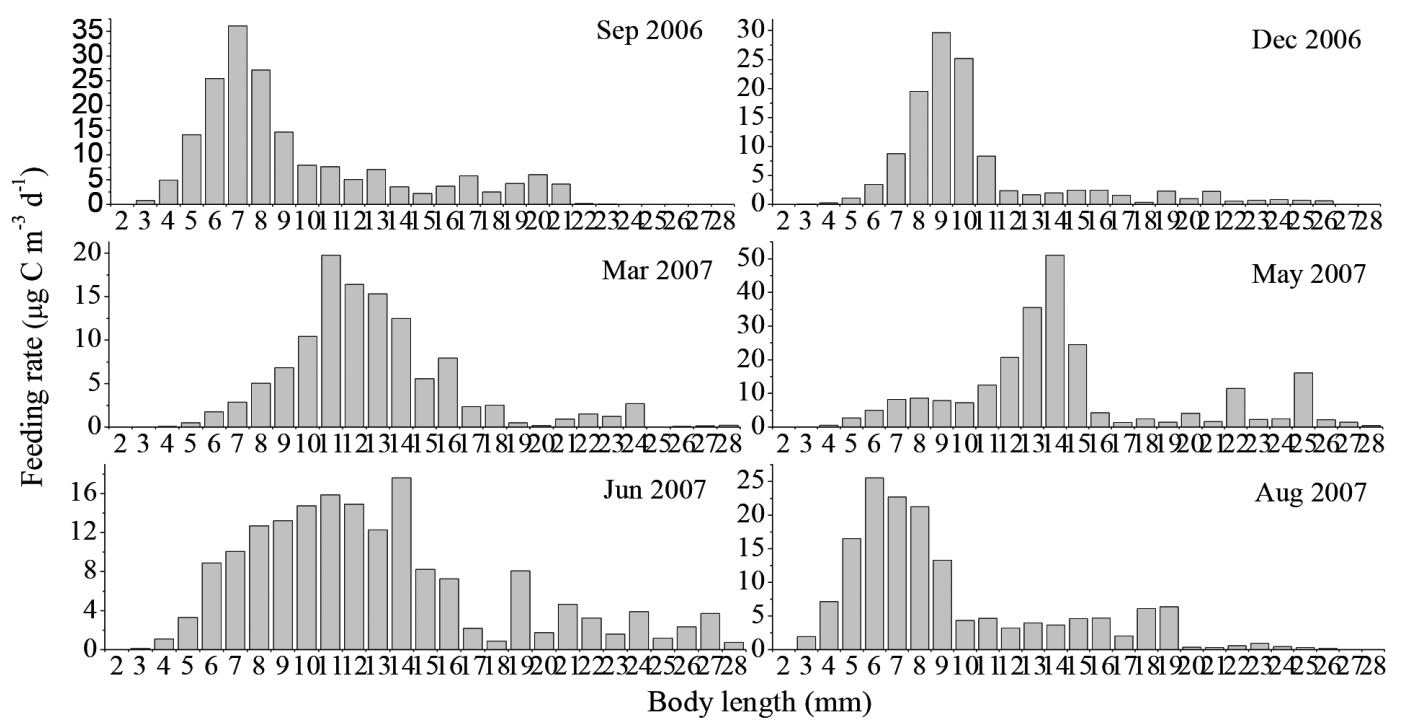

Fig. 5. Relationship between feeding rate and different body length of chaetognaths in investigated months in the Yellow Sea. 


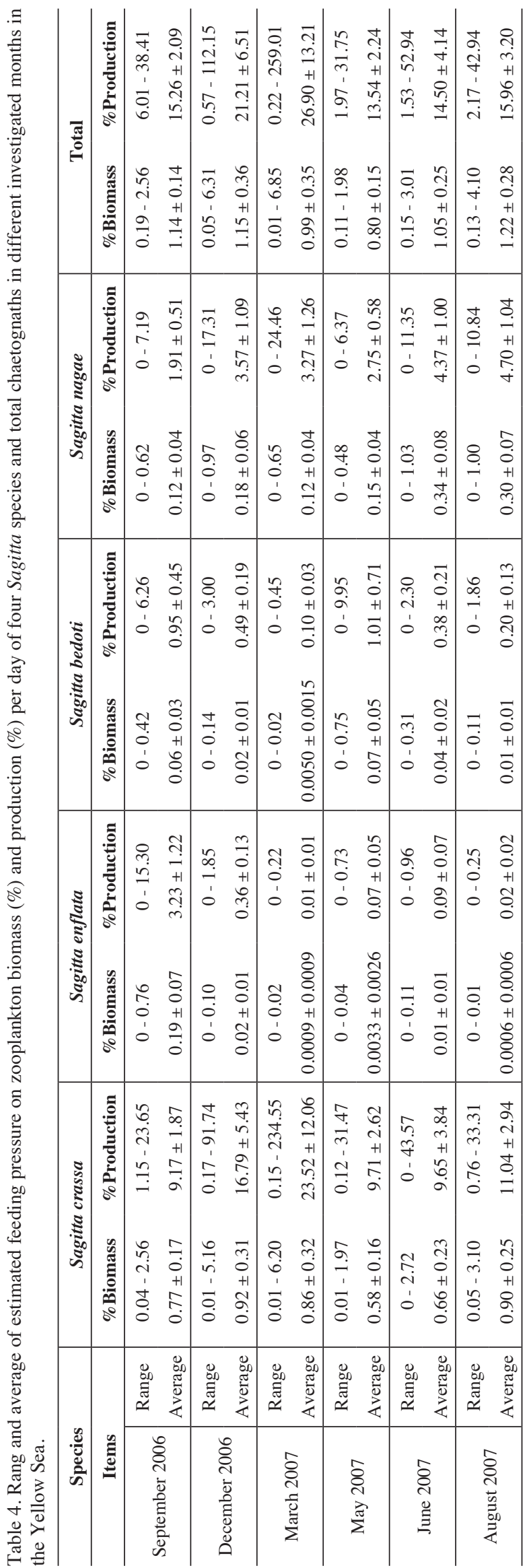

of prey taken per $24 \mathrm{~h}$ ), and $D T$ is digestion time (h), and $N P C$ represents mean number of prey ingested per chaetognath. NPC can be obtained based on the abundance of copepod mandible or chaetognath hooks or other zooplankton detected from the gut content analysis. $D T$ can be evaluated using two methods. The first method is that chaetognaths which contain food in their guts are cultured in situ environmental conditions, and then the digestion time is observed (Feigenbaum and Maris 1984). The other method is that the digestion time is calculated using the empirical equation: $D T=10.96 \mathrm{e}^{-0.086 \mathrm{~T}}$ derived for the Sagitta species by Stuart and Verheye (1991).

The accuracy of the quantitative analysis of gut contents in samples collected by planktonic nets can be affected by various factors. Among the main factors that can cause uncertainties in the estimates is the cod-end feeding and also the regurgitation and evacuation of prey during the handling and preservation processes (Kehayias 2003). Baier and Purcell (1997a) indicated that tow duration should be minimized and prey in the foregut from gut content analysis should be excluded in order to reduce errors due to codend feeding, and they also reported that prey loss due to evacuation can be as much as $50 \%$ of the total prey in tows of greater than 2 min duration, so some researcher suggest that the NPC values in the above feeding rate equation were multiplied by two (Baier and Purcell 1997b; Kehayias et al. 2005). In addition, the possibility of chaetognaths regurgitating their prey during sampling can't be discounted (Feigenbaum and Maris 1984). Feigenbaum and Maris (1984) reviewed digestion times of some chaetognath species evaluated in laboratory or in situ environmental conditions. However, it is evident that digestion time at any temperature can be extremely variable because of the size, type, abundance, chemical composition of prey, as well as the size, development stage of chaetognath species, and that variation between species may not be as great as within species (Stuart and Verheye 1991; Øresland 2000).

The Ikeda-Motoda's physiological methods is convenient to be used to calculate feeding and production of chaetognaths if body weight and water temperature were obtained (Ikeda and Motoda 1978; Ikeda 1985). However, the gross growth efficiency and assimilation efficiency of 0.3 and 0.7 (Hirst and Sheader 1997; Ikeda 1985; Runge and Roff 2000) may vary greatly due to different species (Alldredge 1984; Omori and Ikeda 1984). And the coefficient between the feeding rate, and production and respiration rate is also affected by various factors, such as chaetognath species, water temperature, size and type of prey.

In the present study, we checked the gut contents of four Sagitta species on board during the investigated period, but few Sagitta had food in their gut, and these few Sagitta had hardly excreted over long time mainly because of environmental change. The choice of which of the methods mentioned above depends on the research questions and in 
some cases, a global model of growth may be a sufficient approximation of growth and reproductive rates of zooplankton (Runge and Roff 2000). Therefore, Ikeda and Motoda's physiological model was selected to estimate feeding rate and production of chaetognaths based on the body weight and water temperature in the present study, which has been applied in other several studies (Nagasawa 1991).

\subsection{Biomass and Production of Chaetognaths in the Yellow Sea}

Table 5 showed proportions of biomass and production of chaetognaths to total biomass and production of zooplankton (Huo et al. 2012) in the Yellow Sea. Even though chaetognaths had highest biomass in May 2007, but only contributed $6.63 \%$ to total biomass of zooplankton in the Yellow Sea. The biomass of chaetognaths occupied as high as $13.61 \%$ of total zooplankton biomass even though they had relatively low biomass in December 2006. And in other months, chaetognaths contributed $6.73-12.73 \%$ to total zooplankton biomass. Contributions of chaetognaths to total zooplankton production were lower compared with those to total zooplankton biomass in the Yellow Sea. It was indicated that $S$. crassa and S. nagae dominated the chaetognath community whole year based on their biomass and production in the Yellow Sea. Sagitta crassa has five generations in the Yellow Sea and in adjacent sea areas (Nagasawa 1991; Huo et al. 2010). And these five generations of S. crassa overlapped during whole year in the Yellow Sea and in Tokyo Bay (Nagasawa 1991; Huo et al. 2010), which indicated that $S$. crassa can reproduce and grow under environmental conditions of whole year in the Yellow Sea. This was the main reason that $S$. crassa had relative high biomass compared with other Sagitta species in the Yellow Sea, especially from December to next June. Sagitta nagae had six cohorts throughout the year in Suruga Bay and peak numbers of all stages occurred between May and August (Nagasawa and Marumo 1978). In the present study, S. nagae also had relative high biomass during the period from May to August.

Carbon content was considered as $36.7 \%$ of dry weight in chaetognaths group (Kiørboe 2013). So average production rate $(\mathrm{P} / \mathrm{B})$ of chaetognaths can be calculated based on the average biomass and production in different investigated months in the Yellow Sea (Fig. 6). Average production of chaetognaths was highest with $64.39 \mu \mathrm{g} \mathrm{C} \mathrm{m}^{-3} \mathrm{~d}^{-1}$ in May 2007 , but the average production rate was only $3.15 \% \mathrm{~d}^{-1}$ because of relatively low water temperature (Huo et al. 2012). The average production rate of chaetognaths was as high as 4.79 and 4.73\% d ${ }^{-1}$ in September 2006 and August 2007, respectively, because of relatively high water temperature even though their low standing stock in the Yellow Sea. Chaetognath production occupied $6.58 \%$ of total zooplankton production in December 2006, and only contributed 3.17\% to total zooplankton production in May 2007 (Table 5).
The YSCBW had a vital role in zooplankton biomass and production distributions from June to September in the Yellow Sea (Huo et al. 2008, 2012). Sagitta enflata, S. nagae, and $S$. bedoti were not impacted by the YSCBW because they mostly distributed in the upper layer, but $S$. crassa was impacted because it inhabited mostly inside the thermocline in the Yellow Sea (Zuo et al. 2004). Therefore, S. crassa production was strongly impacted by the YSCBW in September 2006, June and August 2007. In these sampling months, the production rate of $S$. crassa ranged from $3.57-4.69 \% \mathrm{~d}^{-1}$ inside the YSCBW sea area, while $5.09-6.74 \% \mathrm{~d}^{-1}$ outside the cold water mass sea area (data not shown).

The distribution patterns of chaetognaths were mainly impacted by some environmental factors in the Yellow Sea. Sagitta crassa was considered as a coastal species which had abilities to suit to wild temperature and salinity ranges (Nagai et al. 2006), and the spatial-geographical distribution patterns of $S$. crassa were also affected by food availability. Liu et al. (2003) reported that the high biomass of every development stages of Calanus sinicus was found at the same area of $S$. crassa distribution, and Zuo et al. (2006) also reported that the as much as $1.80-3.52 \times 10^{5}$ ind $\mathrm{m}^{-2}$ of small copepod distributed at these sea areas. It was showed that the relatively high biomass of $S$. nagae was distributed in the central and southern part of the study area in the Yellow Sea. Xiao (2004) renamed S. nagae as Sagitta sinica which was a new species in the Yellow Sea. Sagitta sinica was described as a warm-temperate neritic species and was wildly distributed in the Yellow Sea and East China Sea (Xiao 2004). It is necessary to confirm whether it is a new species based on combinations of morphological, molecular and other methods in the future. The distribution mechanism of S. enflata and $S$. bedoti was different between warm seasons and cold seasons in the Yellow Sea. In warm seasons, the expansion of these two Sagitta species was mainly caused by water temperature rise and was not by current transportation (Wang et al. 2003). While in cold seasons, they were mainly impacted by physical transportation and could be transported up to 36 degree north latitude into northern Yellow Sea by the Yellow Sea Warm Current (Wang and Zuo 2004).

\subsection{Feeding Pressure on the Zooplankton in the Yellow Sea}

Feeding pressure on biomass and production of zooplankton by specific species of chaetognaths in different sea areas was summarized in Table 6. Feeding pressure of chaetognaths on zooplankton biomass in the Yellow Sea was lower than that in Kaneohe Bay (Kimmerer 1984), in Aegean Sea (Kehayias et al. 2005) and in Mediterranean (Kehayias 2003), but was similar with that in Southern Ocean (Froneman et al. 1998). Sagitta friderici, Sagitta setosa, Sagitta tenuis, and S. enflata exerted the high feeding pressure on zooplankton biomass in South Afirica, Black Sea, 
Chesapeake Bay, and Chile Sea than those of Sagitta species in the Yellow sea (Canino and Grant 1985; Drits and Utkina 1988; Stuart and Verheye 1991; Giesecke and González 2004). Feeding pressure on zooplankton production by chaetognaths was different from those on biomass (Table 6). Sagitta elegans and Sagitta hispida feed 36 and $100 \%$ on zooplankton production in Bedford Basin and Card Sound, respectively, which were higher than those of chaetognaths in the Yellow Sea (Sameoto 1973; Reeve and Baker 1975). While the feeding pressure of $S$. crassa on zooplankton production in the Yellow Sea was higher than that of S. crassa in Tokyo Bay (Nagasawa 1991), and higher than other Sagitta species in other sea areas (Sameoto 1972; Feigenbaum 1977; Canino and Grant 1985; Froneman et al. 1998).

Copepod is commonly reported as being the most abundant food item found in chaetognath guts because of its abundance in the marine habitat (Feigenbaum 1991). It was reported that the feeding of chaetognaths was more serious for the copepod community in their lower production period (Baier and Purcell 1997b). Sameoto (1973) indicated that the average feeding pressure of S. elegans on copepod production was $1 \%$, but increased up to $50 \%$ during winter time in Bedford Basin. Øresland (1990) discovered that $E u$ krohnia hamata averagely feed on $0.03-0.06 \%$ of copepod biomass, but $12 \%$ of copepod biomass was fed during their diapause stages during winter time in Southern Ocean. In the present study, the feeding pressure of chaetognaths on zooplankton production was also highest during cold seasons in December 2006 and March 2007 with 21.21 and $26.90 \%$, respectively, which indicated that the feeding of chaetognaths had important impacts on zooplankton community structure and production, especially on copepod.

\subsection{Feeding Impacts of Chaetognaths on Different Body Length of Zooplankton}

Body size of zooplankton was an important factor on determining the composition of food item fed by chaetognaths (Rakuza-Suszczewski 1969; Sullivan 1980), which indicated that feeding pressure of chaetognaths on different

Table 5. Contributions of chaetognaths to total the biomass (mg DM m $\left.\mathrm{m}^{-3} \mathrm{~d}^{-1}\right)$ and production $\left(\mathrm{mg} \mathrm{C} \mathrm{m}^{-3} \mathrm{~d}^{-1}\right)$ of zooplankton in different months in the Yellow Sea.

\begin{tabular}{c|cccc}
\hline Months & Items & Chaetognaths & Total zooplankton & Proportion (\%) \\
\hline \multirow{2}{*}{ September 2006 } & Biomass & 2.85 & 42.34 & 6.73 \\
& Production & 0.050 & 1.44 & 3.49 \\
\hline \multirow{2}{*}{ December 2006 } & Biomass & 2.97 & 21.83 & 13.61 \\
& Production & 0.033 & 0.51 & 6.58 \\
\hline \multirow{2}{*}{ March 2007 } & Biomass & 4.12 & 32.37 & 12.73 \\
& Production & 0.033 & 0.67 & 4.98 \\
\hline \multirow{2}{*}{ May 2007 } & Biomass & 5.57 & 84.03 & 6.63 \\
& Production & 0.064 & 1.97 & 3.27 \\
\hline \multirow{2}{*}{ June 2007 } & Biomass & 3.74 & 38.36 & 9.75 \\
& Production & 0.050 & 1.37 & 3.68 \\
\hline \multirow{2}{*}{ August 2007 } & Biomass & 2.56 & 27.17 & 9.42 \\
& Production & 0.044 & 0.81 & 5.48 \\
\hline
\end{tabular}

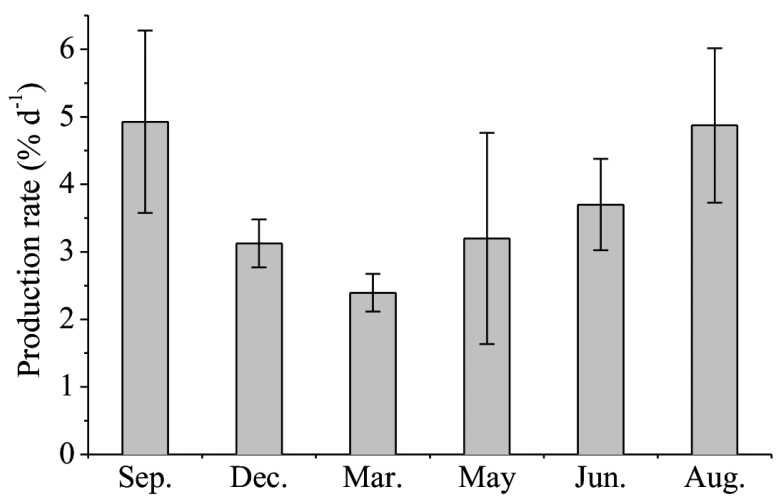

Fig. 6. Production rate (mean $\pm \mathrm{SD}$ ) of chaetognaths in different investigated months in the Yellow Sea. 
Table 6. Feeding pressure by the different species of chaetognaths on biomass and production of zooplankton in different seas.

\begin{tabular}{|c|c|c|c|c|}
\hline \multirow{2}{*}{ Species } & \multirow{2}{*}{ Sea area } & \multicolumn{2}{|c|}{ Feeding Pressure } & \multirow{2}{*}{ Literature } \\
\hline & & \%Biomass & \% Production & \\
\hline Sagitta crassa & Tokyo Bay & & 10 & Nagasawa 1991 \\
\hline Sagitta elegans & Bedford Basin & & 36 & Sameoto 1973 \\
\hline Sagitta elegans & St. Margaret's Bay & & $0.7-1.0$ & Sameoto 1972 \\
\hline Chaetognaths & Kaneohe Bay & $4-12$ & & Kimmerer 1984 \\
\hline Sagitta friderici & South Afirica & $1.0-5.3$ & & Stuart and Verheye 1991 \\
\hline Sagitta setosa & Black Sea & $0.3-6$ & & Drits and Utkina 1988 \\
\hline Sagitta tenuis & Chesapeake Bay & $1-4$ & $5-15$ & Canino and Grant 1985 \\
\hline Sagitta enflata & Gulf Stream & & 6.1 & Feigenbaum 1977 \\
\hline Sagitta hispida & Card Sound & & 100 & Reeve and Baker 1975 \\
\hline Sagitta enflata & Zanzibar Channel & 1 & & Øresland 2000 \\
\hline Chaetognaths & Aegean Sea & $0.02-2.76$ & & Kehayias et al. 2005 \\
\hline Chaetognaths & Mediterranean & $0.3-7.8$ & & Kehayias 2003 \\
\hline Sagitta enflata & Chile Sea & $0.4-6$ & & Giesecke and González 2004 \\
\hline Eukrohnia hamata and Sagitta gazellae & Southern Ocean & $0.3-1.2$ & $7-16$ & Froneman et al. 1998 \\
\hline Sagitta crassa & Yellow Sea & $0.58-0.92$ & $9.17-23.52$ & Present study \\
\hline Sagitta nagae & Yellow Sea & $0.12-0.34$ & $1.91-4.70$ & Present study \\
\hline Sagitta enflata & Yellow Sea & $0.0006-0.19$ & $0.01-3.23$ & Present study \\
\hline Sagitta bedoti & Yellow Sea & $0.005-0.07$ & $0.10-1.01$ & Present study \\
\hline Chaetognaths & Yellow Sea & $0.80-1.22$ & $13.54-26.90$ & Present study \\
\hline
\end{tabular}

body length of zooplankton was obvious distinct. There was a positive relationship between body length of chaetognaths and their food: $\mathrm{H}=a P^{\mathrm{b}}$ (Pearre 1980), but Sullivan (1980) indicated that chaetognaths did not have directly food selection. S. nagae did not showed food selection when the body width of copepod was in the range of $0.2-1.2 \mathrm{~mm}$ in Suruga Bay (Nagasawa and Marumo 1976). Yang and Li (1995) reported that the body length of zooplankton from $0.7 \mathrm{~mm}$ (e.g., Paracalanus parvus) to $2.3 \mathrm{~mm}$ (e.g., Calanus sinicus) was the main food of $S$. crassa in the Yellow Sea. Although adults of chaetognaths can feed on wide size spectrum of zooplankton, there exactly occurred difference on food size ranges at their different development stages (Sullivan 1980). Saito and Kiørboe (2001) demonstrated that feeding rates of $S$. elegans were affected by prey size, prey swimming behavior and small-scale turbulence, and it had highest feeding rates when the prey size was $6-10 \%$ of their body length. So in the present study, effects of feeding on different size spectrum of zooplankton by chaetognaths were evaluated in the Yellow Sea based on $6-10 \%$ of prey size to body length of chaetognaths. Based on this assumption, chaetognaths had highest feeding rate on the body length with 0.6 - $1.6 \mathrm{~mm}$ of zooplankton in March, May, and June 2007, which indicated that chaetognaths mainly feed on small copepod, such as Paracalanus parvus, Cen- tropages mcmurrichi, Oithona similis, and individuals of large copepod at their development stages, such as Calanus sinicus (Sun et al. 2010; Huo et al. 2012), and in September 2006, December 2006, and August 2007, chaetognaths mainly fed on small copepod and nauplius and copepodite of large copepod due to the highest feeding rate on the body length with $0.5-1.1 \mathrm{~mm}$ of zooplankton in the Yellow Sea. Therefore, the biomass and production of small copepods, and nauplius and copepodite of large copepods would be impacted during whole year in the Yellow Sea. Calanus sinicus was the absolute dominant species in the Yellow Sea (Sun 2005; Sun and Zhang 2005). Calanus sinicus was in the diapause stage in the summer time in the Yellow Sea (Pu et al. 2004), and had lowest production in this period (Zhang et al. 2005, 2007; Huo et al. 2008), which indicated that $C$. sinicus would be impacted seriously by the feeding of chaetognaths in the summer time in the Yellow Sea.

Acknowledgements We would like to thank crew on R/V "BeiDou" for their assistance in the field, and thank Prof. D. $\mathrm{J}$. Huang and $\mathrm{H}$. Wei for providing the CTD profiles. Support from the MOST (PN: 2006CB400606) and the NSFC (No. 40631008) to S. Sun and NSFC (NO. 40606036) to F. Zhang are acknowledged. Thanks are also due to the anonymous reviewers for their valuable comments and suggestions. 


\section{REFERENCES}

Alldredge, A. L., 1984: The quantitative significance of gelatinous zooplankton as pelagic consumers. In: Fasham, M. J. R. (Ed.), Flows of Energy and Materials in Marine Ecosystems: Theory and Practice, NATO Conference Series, Vol. 13, Springer, Boston, MA, 407433, doi: 10.1007/978-1-4757-0387-0_16. [Link]

Baier, C. T. and J. E. Purcell, 1997a: Effects of sampling and preservation on apparent feeding by chaetognaths. Mar. Ecol. Prog. Ser., 146, 37-42, doi: 10.3354/ meps146037. [Link]

Baier, C. T. and J. E. Purcell, 1997b: Trophic interactions of chaetognaths, larval fish and zooplankton in the South Atlantic Bight. Mar. Ecol.Prog. Ser., 146, 43-53, doi: 10.3354/meps 146043. [Link]

Bajkov, A. D., 1935: How to estimate the daily food consumption of fish under natural conditions. Trans. Am. Fish. Soc., 65, 288-289, doi: 10.1577/1548-8659(1935)65[288:HTETDF]2.0.CO;2. [Link]

Canino, M. F. and G. C. Grant, 1985: The feeding and diet of Sagitta tenuis (Chaetognatha) in the Lower Chesapeake Bay. J. Plankton Res., 7, 175-188, doi: 10.1093/ plankt/7.2.175. [Link]

Choi, J.-W . and W .-G. Park, 2013: Variations of Marine Environments and Zooplankton Biomass in the Yellow Sea During the Past Four Decades. Journal of Fisheries and Marine Sciences Education, 25, 1046-1054, doi: 10.13000/jfmse.2013.25.5.1046. (in Korean with English abstract) [Link]

Drits, A. V. and S. V. Utkina, 1988: Feeding of Sagitta setosa in the layers of daytime phytoplankton accumulation in the Black Sea. Oceanology, 28, 781-785.

Feigenbaum, D., 1979: Daily ration and specific daily ration of the Chaetognath Sagitta enflata. Mar. Biol., 54, 7582, doi: 10.1007/BF00387053. [Link]

Feigenbaum, D. L., 1977: Nutritional ecology of the Chaetognatha with particular reference to external hair patterns, prey detection, and feeding. Ph.D. Thesis, University of Miami, Florida, USA, 106 pp.

Feigenbaum, D. L., 1991: Food and feeding behavior. In: Bone, Q. (Ed.), Thebiology of Chaetognaths, Oxford University Press, Oxford, 45-54.

Feigenbaum, D. L. and R. C. Maris, 1984: Feeding in chaetognatha. Oceanogr. Mar.Biol.Ann.Rev., 22, 343-392.

Froneman, P. W. and E. A. Pakhomov, 1998: Trophic importance of the chaetognaths Eukrohnia hamata and Sagitta gazellae in the pelagic system of the Prince Edward Islands (Southern Ocean). Polar Biol., 19, 242249, doi: 10.1007/s003000050241. [Link]

Froneman, P. W., E. A. Pakhomov, R. Perissinotto and V. Meaton, 1998: Feeding and predation impact of two chaetognath species, Eukrohnia hamata and $\mathrm{Sa}$ - gitta gazellae, in the vicinity of Marion Island (southern ocean). Mar. Biol., 131, 95-101, doi: 10.1007/ s002270050300. [Link]

Giesecke, R. and H. E. González, 2004: Feeding of Sagitta enflata and vertical distribution of chaetognaths in relation to low oxygen concentrations. J. Plankton Res., 26, 475-486, doi: 10.1093/plankt/fbh039. [Link]

Gnaiger, E., 1983: Calculation of energetic and biochemical equivalents of respiratory oxygen consumption. In: Gnaiger, E. and H. Forstner (Eds.), Polarographic Oxygen Sensors, Springer, Berlin, Heidelberg, 337-345, doi: 10.1007/978-3-642-81863-9_30. [Link]

Hirst, A. G. and M. Sheader, 1997: Are in situ weightspecific growth rates body-size independent in marine planktonic copepods? A re-analysis of the global syntheses and a new empirical model. Mar. Ecol. Prog. Ser., 154, 155-165, doi: 10.3354/meps154155. [Link]

Huo, Y., S. Wang, S. Sun, C. Li, and M. Liu, 2008: Feeding and egg production of the planktonic copepod Calanus sinicus in spring and autumn in the Yellow Sea, China. J. Plankton Res., 30, 723-734, doi: 10.1093/plankt/ fbn034. [Link]

Huo, Y., S. Sun, and B. Yang, 2010: Life cycle of the Chaetognath Sagitta crassa in the southern Yellow Sea, China. Oceanologia Et Limnologia Sinica, 2, 180-185. (in Chinese with English abstract)

Huo, Y., S. Sun, F. Zhang, M. Wang, C. Li, and B. Yang, 2012: Biomass and estimated production properties of size-fractionated zooplankton in the Yellow Sea, China. J. Mar. Syst., 94, 1-8, doi: 10.1016/j.jmarsys.2011.09.013. [Link]

Ikeda, T., 1985: Metabolic rates of epipelagic marine zooplankton as a function of body mass and temperature. Mar. Biol., 85, 1-11, doi: 10.1007/BF00396409. [Link]

Ikeda, T. and S. Motoda, 1975: An approach to the estimation of zooplankton production in the Kuroshio and adjacent regions. In: Morton, B. (Ed.), Special symposium on Marine Sciences. Pacific Science Association Hong Kong, 24-28.

Ikeda, T. and S. Motoda, 1978: Estimated zooplankton production and their ammonia excretion in the Kuroshio and adjacent seas. Fish. Bull., 76, 357-366.

Kang, Y. S., S. Jung, Y. Zuenko, I. Choi, and N. Dolganova, 2012: Regional differences in the response of mesozooplankton to oceanographic regime shifts in the northeast Asian marginal seas. Prog. Oceanogr., 97-100, 120-134, doi: 10.1016/j.pocean.2011.11.012. [Link]

Kehayias, G., 2003: Quantitative aspects of feeding of chaetognaths in the eastern Mediterranean pelagic waters. J. Mar. Biol. Assoc. U.K., 83, 559-569, doi: 10.1017/ S0025315403007483h. [Link]

Kehayias, G., E. Michaloudi, and E. Koutrakis, 2005: Feeding and predation impact of chaetognaths in the north Aegean Sea (Strymonikos and Ierissos Gulfs). $J$. 
Mar. Biol. Assoc. U.K., 85, 1525-1532, doi: 10.1017/ S0025315405012737. [Link]

Kimmerer, W. J., 1984: Selective predation and its impact on prey of Sagitta enflata (Chaetognatha). Mar. Ecol. Prog. Ser., 15, 55-62, doi: 10.3354/meps015055. [Link]

Kiørboe, T., 2013: Zooplankton body composition. Limnol. Oceanogr., 58, 1843-1850, doi: 10.4319/ lo.2013.58.5.1843. [Link]

Kruse, S., T. Brey and U. Bathmann, 2010: Role of midwater chaetognaths in Southern Ocean pelagic energy flow. Mar. Ecol. Prog. Ser., 416, 105-113, doi: 10.3354/meps08773. [Link]

Lee, B. R., H. W. Kim, and W. Park, 2016: Distribution of chaetognaths (Aphragmophora: Sagittidae) in Korean waters. Ocean Sci. J., 51, 447-454, doi: 10.1007/ s12601-016-0040-x. [Link]

Liu, G. M., S. Sun, H. Wang, Y. Zhang, B. Yang, and P. Ji, 2003: Abundance of Calanus sinicus across the tidal front in the Yellow Sea, China. Fish. Oceanogr., 12, 291-298, doi: 10.1046/j.1365-2419.2003.00253.x. [Link]

Mills, C. E., 1995: Medusae, siphonophores, and ctenophores as planktivorous predators in changing global ecosystems. ICES J. Mar. Sci., 52, 575-581, doi: 10.1016/1054-3139(95)80072-7. [Link]

Nagai, N., K. Tadokoro, K. Kuroda, and T. Sugimoto, 2006: Occurrence characteristics of chaetognath species along the PM transect in the Japan Sea during 19722002. J. Oceanogr., 62, 597-606, doi: 10.1007/s10872006-0079-x. [Link]

Nagasawa, S., 1984: Laboratory feeding and egg production in the Chaetognath Sagitta crassa Tokioka. J. Exp. Mar. Biol. Ecol., 76, 51-65, doi: 10.1016/00220981(84)90016-9. [Link]

Nagasawa, S., 1991: Vertical distribution, life cycle and production of the chaetognath Sagitta crassa in Tokyo Bay, Japan. J. Plankton Res., 13, 1325-1338, doi: 10.1093/plankt/13.6.1325. [Link]

Nagasawa, S. and R. Marumo, 1976: Further studies on the feeding habits of Sagitta nagae Alvariño in Suruga Bay, central Japan. J. Oceanogr., 32, 209-218, doi: 10.1007/BF02107123. [Link]

Nagasawa, S. and R. Marumo, 1978: Reproduction and life history of the Chaetognath Sagitta nagae Alvariño in Suruga Bay. Bull. Plankton Soc. Japan, 25, 67-84.

Omori, M. and T. Ikeda, 1984: Methods in Marine Zooplankton Ecology, John Wiley and Sons, New York, $332 \mathrm{pp}$.

Øresland, V., 1990: Feeding and predation impact of the chaetognath Eukrohnia hamata in Gerlache Strait, Antarctic Peninsula. Mar. Ecol. Prog. Ser., 63, 201209, doi: 10.3354/meps063201. [Link]

Øresland, V., 2000: Diel feeding of the chaetognath Sagitta enflata in the Zanzibar Channel, western Indian Ocean. Mar. Ecol. Prog. Ser., 193, 117-123, doi: 10.3354/ meps 193117. [Link]

Pearre, S., 1980: Feeding by Chaetognatha: The relation of prey size to predator size in several species. Mar. Ecol. Prog. Ser., 3, 125-134, doi: 10.3354/meps003125. [Link]

Pu, X.-M., S. Sun, B. Yang, G.-T. Zhang, and F. Zhang, 2004: Life history strategies of Calanus sinicus in the Southern Yellow Sea in summer. J. Plankton Res., 26, 1059-1068, doi: 10.1093/plankt/fbh101. [Link]

Rakuza-Suszczewski, S. J., 1969: The food and feeding habits of chaetognatha in the seas around the British Isles. Polsk. Arch. Hydrobiol., 16, 213-232.

Reeve, M. R., 1970: The biology of chaetognatha. I. Quantitative aspects of growth and egg production in Sagitta hispida. In: Steele, J. H. (Ed.), Marine Food Chains, Oliver and Boyd, Edinburgh, 168-189.

Reeve, M. R. and L. D. Baker, 1975: Production of two planktonic carnivores (chaetognath and ctenophore) in South Florida inshore waters. Fish. Bull., 73, 238-248.

Runge, J. A. and J. C. Roff, 2000: The measurement of growth and reproductive rates. In: Harris, R. P., P. H. Wiebe, J. Lenz, H. R. Skjoldal, and M. Huntley (Eds.), ICES Zooplankton Methodology Manual, Academic Press, London, 401-454, doi: 10.1016/B978012327645-2/50010-4. [Link]

Saito, H. and T. Kiørboe, 2001: Feeding rates in the chaetognath Sagitta elegans: Effects of prey size, prey swimming behaviour and small-scale turbulence. J. Plankton Res., 23, 1385-1398, doi: 10.1093/plankt/23.12.1385. [Link]

Sameoto, D. D., 1972: Yearly respiration rate and estimated energy budget for Sagitta elegans. J. Fish. Res. Board Can., 29, 987-996, doi: 10.1139/f72-143. [Link]

Sameoto, D. D., 1973: Annual life cycle and production of the chaetognath Sagitta elegans in Bedford Basin, Nova Scotia. J. Fish. Res. Board Can., 30, 333-344, doi: 10.1139/f73-063. [Link]

Stuart, V. and H. M. Verheye, 1991: Diel migration and feeding patterns of the chaetognath, Sagitta friderici, off the west coast of South Africa. J. Mar. Res., 49, 493-515, doi: 10.1357/002224091784995819. [Link]

Sullivan, B. K., 1980: In situ feeding behavior of Sagitta elegans and Eukrohnia hamata (Chaetognatha) in relation to the vertical distribution and abundance of prey at Ocean station "P". Limnol. Oceanogr., 25, 317-326, doi: 10.4319/lo.1980.25.2.0317. [Link]

Sun, S., 2005: Over-summering strategy of Calanus sinicus. GLOBEC Newsletter, 11, 34 .

Sun, S. and G. T. Zhang, 2005: Over-summering strategy of Calanus sinicus. IGBP Newsletter, 62, 12-13.

Sun, S., Y. Huo, and B. Yang, 2010: Zooplankton functional groups on the continental shelf of the Yellow Sea. 
Deep-Sea Res. Part II-Top. Stud. Oceanogr., 57, 10061016, doi: 10.1016/j.dsr2.2010.02.002. [Link]

Terazaki, M., 2001: Ecology of chaetognaths. Monthly Kaiyo, 27, 191-197. (in Japanese with English abstract)

Uye, S., 1982: Length-weight relationships of important zooplankton from the Inland Sea of Japan. J. Oceanogr.Soc.Jpn., 38, 149-158, doi: 10.1007/BF02110286. [Link]

Wang, R. and K. Wang, 2003: Field test of capture capabilities of two plankton nets. J. Fish. China, 27, 98-102. (in Chinese with English abstract)

Wang, R. and T. Zuo, 2004: The Yellow Sea Warm Current and the Yellow Sea Cold Bottom Water, their impact on the distribution of zooplankton in the Southern Yellow Sea. J. Soc. Oceanogr. Korean, 39, 1-13.

Wang, R., S. W. Gao, K. Wang, and T. Zuo, 2003: Zooplankton indication of the Yellow Sea Warm Current in winter. J. Fish. China, 27, 39-48. (in Chinese with English abstract)

Xiao, Y., 2004: Fauna Sinica Invertebrata (Vol.38) Chaetognatha: Sagittoidea, Science Press, Beijing, 105-110.
Yang, G. and J. Li, 1995: Study on the feeding of the Bohai Sea Sagitta crassa.Mar. Sci., 6, 38-42. (In Chinese with English abstract)

Zhang, G.-T., S. Sun, and F. Zhang, 2005: Seasonal variation of reproduction rates and body size of Calanus sinicus in the Southern Yellow Sea, China. J. Plankton Res., 27, 135-143, doi: 10.1093/plankt/fbh164. [Link]

Zhang, G.-T., S. Sun, and B. Yang, 2007: Summer reproduction of the planktonic copepod Calanus sinicus in the Yellow Sea: Influences of high surface temperature and cold bottom water. J. Plankton Res., 29, 179-186, doi: 10.1093/plankt/fbm005. [Link]

Zuo, T., R. Wang, K. Wang, and S. W. Gao, 2004: Vertical distribution and diurnal migration of zooplankton in the southern Yellow Sea in summer. Acta Ecologica Sinica, 24, 524-530. (in Chinese with English abstract)

Zuo, T., R. Wang, S. Gao, and K. Wang, 2006: Abundance of small-sized copepods in anchovy Engraulis japonicus spawning ground in Southern Yellow Sea. Oceanol. Limnol. Sin., 37, 330-336. (in Chinese with English abstract) 